\title{
"Don't be so melodramatic!" Dickens and the affective mode
}

\section{Sally Ledger}

One of the most affecting tableaux in Dickens's fiction is in the fifth monthly instalment of Dombey and Son when the "swift river" finally bears young Paul Dombey out into the ocean that has so preoccupied him throughout his short life. Dickens's friend, Lord Jeffrey, wrote to him in effusive terms:

Oh my dear, dear Dickens, what a number 5 you have given us! I have so cried and sobbed over it last night, and again this morning; and felt my heart purified by those tears, and blessed and loved you for making me shed them. ${ }^{1}$

Such responses were not unusual, and even the author himself often wept in pity for his fictional characters. Dickens confided to his friend John Forster that as he had finished writing The Chimes, the second of his Christmas Books, he had had "what women call 'a real good cry!"'² Dickens's friends and associates were equally enthusiastic about the story. On 2 December 1844 an invited private audience gathered together in Lincoln's Inn Fields for Dickens's reading of the full text in advance of publication. Daniel Maclise's sketch of the performance (see figure 1) includes most of the audience, which comprised

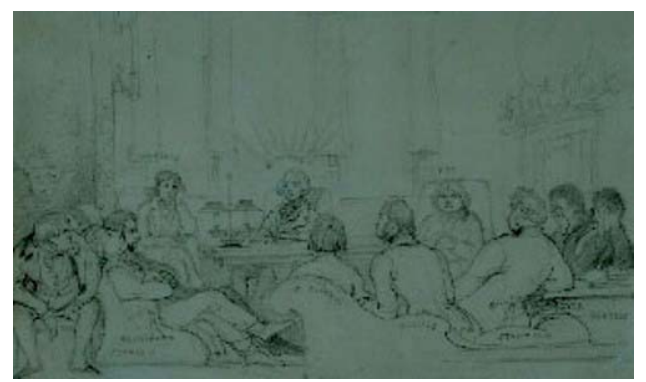

Figure 1 Maclise, Dickens Reading the

Figure
Douglas Jerrold, John Forster, Thomas Carlyle, the actor William Charles Macready, the Reverends William J. Fox and William Harness, Blanchard Laman, Alexander Dyce and Frederick Dickens. In a letter to Catherine Dickens that accompanied his sketch, Maclise reported that:

... there was not a dry eye in the house ... We should borrow the high language of the minor theatre and even then not do the effect justice - shrieks of laughter - there were indeed - and floods of tears as a relief to them - I do not think that there ever was such a triumphant hour for Charles.$-^{3}$

Dickens himself wrote to his wife about a member of his audience who is not included in Maclise's sketch, the actor William Charles Macready who had, Dickens observed, been "undisguisedly sobbing, and crying on the sofa, as I read." ${ }^{4}$ Dickens also noted with a certain amount of glee that on another, slightly earlier occasion, John Forster had read the

Sally Ledger, “Don’t be so melodramatic!” Dickens and the affective mode.

19: Interdisciplinary Studies in the Long Nineteenth Century, 4 (2007) 
story to the popular journalist and Dickens plagiarist Gilbert À Beckett, with a similar result:

Anybody who has heard it [The Chimes] has been moved in the most extraordinary manner. Forster read it (for dramatic purposes) to À Beckett - not a man of very quiet feeling. He cried so much, and so painfully, that Forster didn't know whether to go on or stop; and he [À Beckett] called next day to say that any expression of his feeling was beyond his power. But that he believed it, and felt it, to be - I won't say what. ${ }^{5}$

I want to use these two accounts of the first readings of The Chimes, and Maclise's sketch, as a starting point for my discussion of the affective mode in Dickens's writings and in his performances of them. Dickens's often spectacular performances of his works of fiction were greatly abetted by the theatrical mode of his writing, and in the first part of this essay I will demonstrate the aesthetic mechanisms of this theatricality in an account of a series of tableaux in Oliver Twist. In the second part of the essay I will examine the effects of the shifts of emotional register in Dickens's writing, from laughter to tears, and from pathos to satire so as to illuminate Maclise's reflections on the 'shrieks of laughter' and 'floods of tears' provoked by Dickens's reading of his work.

Maclise refers to the need for "the high language of the minor theatre" - by which he means the language of the melodrama - to do justice to the "effect" of Dickens's reading of The Chimes. The phrase that Maclise uses - "not a dry eye in the house" - also suggests a theatrical mode. Forster, we learn, was reading the story to Gilbert À Beckett "for dramatic purposes" - À Beckett and Mark Lemon had been authorised in advance by Dickens to produce a staged version of the story. Dickens's affective mode is, then, highly theatrical and performative. Martin Meisel has written in his study of the relationship between narrative, theatrical and pictorial arts in the nineteenth century, that "[...] Dickens of all Victorian novelists made the most of the theatrical art of his day - made more of it than any of the playwrights."6

The staged, performed nature of the reading of The Chimes - and of Dickens's deployment of the melodramatic mode more generally - is highly significant. Dickens had been most particular in instructing Forster as to who should be present at the private reading, and was disappointed that Jane Carlyle - the only female invitee - could not be there. Maclise's sketch is itself a carefully ordered composition: it is interesting in this respect that Macready is left out, his sobbing on the sofa perhaps insufficiently controlled or staged (oddly enough, given that he was an actor). One also perhaps detects a certain

Sally Ledger, “Don’t be so melodramatic!” Dickens and the affective mode.

19: Interdisciplinary Studies in the Long Nineteenth Century, 4 (2007) 
discomfort in John Forster's reported unease when Gilbert À Beckett's emotional response to The Chimes ran out of control - "he cried so much, and so painfully, that Forster didn't know whether to go on or stop". The staged, performed nature of affect is, I want to suggest, central to an understanding of Dickens's engagement with the melodramatic mode. This is not to say, though, that his ability to provoke uncontained emotional responses did not delight him - there is plenty of evidence in his letters that it did. Apropos of Macready, for example, he told his wife, "If you had seen [him] ... you would have felt (as I did) what a thing it is to have Power." ${ }^{7}$ It was also of paramount importance to Dickens, though, that such emotional outpourings should have an instrumental effect. That they did have a pragmatic purpose and effect is indicated in a letter that the Countess of Blessington wrote to John Forster concerning The Chimes: "Yes, this book will melt hearts and open purse strings ... I was embarrassed to meet the eyes of my servants, mine were so red with tears." ${ }^{8}$ The Countess's reference to the opening of purse strings is heavily freighted here, as Dickens's writing had, arguably, an unprecedented 'double' effect in the literary market place. On the one hand, the emotional affects of his writings were designed to promote individual charity as well as to plead on behalf of systemic social change; on the other hand, his exploitation of the melodramatic mode played to the widest popular audience so as to maximise the commercial success of his writing projects, in the process making him a very rich man.

Maclise writes of the "effect" of Dickens's reading, and Martin Meisel has used the term "effect" to describe a particular type of dramatic and/or pictorial tableau in which the action and the emotions that it produces are temporarily arrested, frozen in time. Maclise's sketch is exactly this kind of tableau; Dickens's novels (and Cruikshank's illustrations for Oliver Twist immediately spring to mind) are full of them. Of Cruikshank's tableaux one thinks immediately of the now culturally iconographic moment when Oliver asks for more gruel - a moment in the novel

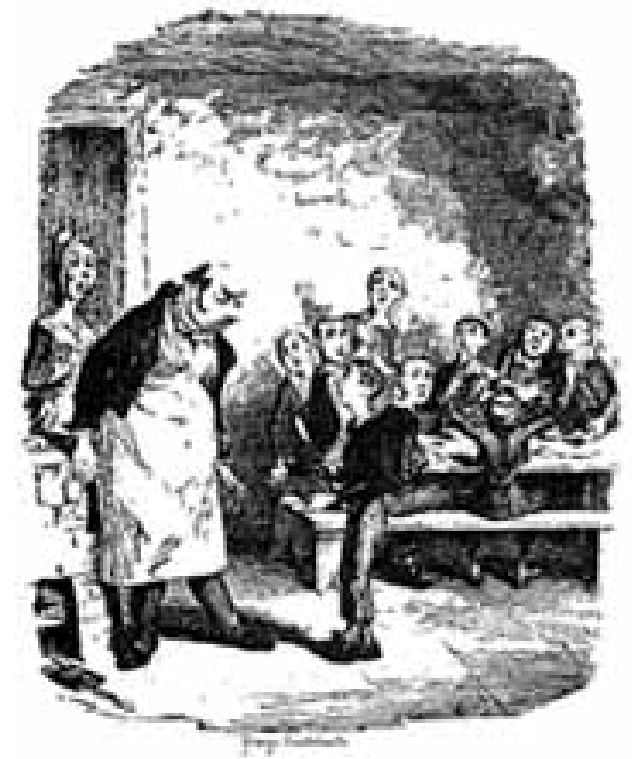
that crystallizes for the reader a whole range of its meanings (see figure 2). Cruikshank's illustration

Fig 2 Oliver asking for more

Sally Ledger, “Don’t be so melodramatic!” Dickens and the affective mode.

19: Interdisciplinary Studies in the Long Nineteenth Century, 4 (2007) www.19.bbk.ac.uk 
gestures powerfully towards the consumption trope, derived from the science of political economy that wielded such ideological power in the early Victorian period, which the young Dickens attacks with such alacrity in his novel from 1837-39. Another tableau, or in Meisel's terms an "effect", is achieved when an absent-minded, preoccupied magistrate suddenly notices that young Oliver is sobbing in terror at the prospect of being apprenticed to a chimney sweep (see figure 3). The magistrate decides at the last moment not to sign the indentures; his brief moment of emotional perception and engagement changes the course of Oliver's life:

It was the critical moment of Oliver's fate. If the inkstand had been where the old gentleman thought it was, he would have dipped his pen into it and signed the indenture, and Oliver would have been straightway hurried off. But, as it chanced to be immediately under his nose, it followed as a matter of course that he looked all over his desk for it, without finding it; and happening in the course of his search to look straight before him, his gaze encountered the pale and terrified face of Oliver Twist, who, despite all the admonitory looks and pinches of Bumble, was regarding the very repulsive countenance of his future master with a mingled expression of horror and fear, too palpable to be mistaken even by a half-blind magistrate. ${ }^{9}$

Characteristically Dickens combines the emotional affect produced by the sobbing, terrified Oliver with a caustic critique of the arbitrariness and lazy arrogance of the law. When the magistrate perceives the boy's terror, his response is humane: but the emphasis in the text and in Cruikshank's illustration is on his inert absent-mindedness, on the arrogance of his newspaperreading colleague, and on the pompous snuff-taking of the Guardian of the workhouse. As always in Dickens, melodramatic affect is combined with social or political critique.

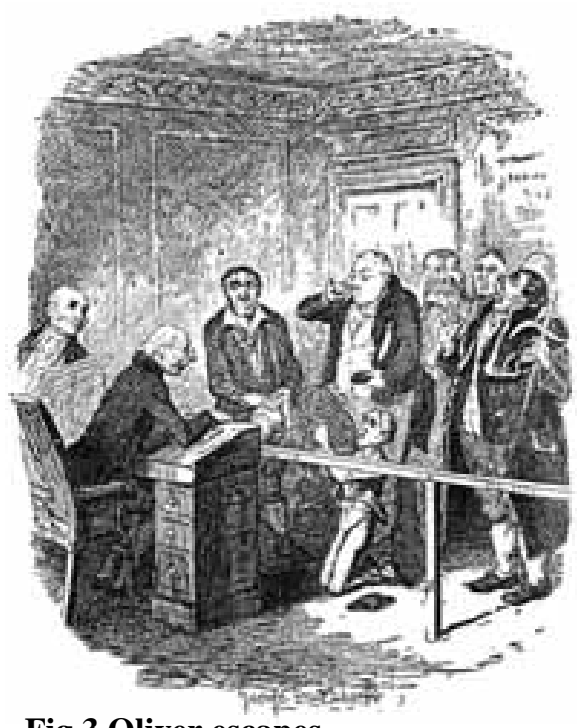

Fig 3 Oliver escapes

The third tableau from Oliver Twist I want briefly to discuss here is the recognition scene in which Oliver's attention is caught by a portrait of the woman who, it later transpires, was his mother (see figure 4). Dickens borrows and adapts this scene from a play from 1832 by Richard Brinsley Peake, The Climbing Boy, or, The Little Sweep which, as Kate Newey has noted, must certainly have been one of the sources for Oliver Twist. ${ }^{10}$ The little sweep of Brinsley's title is a young boy of genteel family who has been forcibly separated from his mother and put to work as a chimney sweep. By a series of

Sally Ledger, “Don’t be so melodramatic!” Dickens and the affective mode.

19: Interdisciplinary Studies in the Long Nineteenth Century, 4 (2007) 
extraordinary coincidences he is finally restored both to her, and to his rightful station in society. During the course of the play's movement towards their joyful reunion the little sweep loses himself in a maze of chimneys during a working day in London. Finding himself in the bedroom of a genteel house, he half recognises his surroundings, and the recognition is crystallized when his gaze alights upon a portrait on the bedroom wall:

[Boy]: (Sobs) Oh, what a miserable life I lead! I, who recollect a kind nurse, and comfortable home, when I used to lie down on a bed (Looks at the bed.) ... (Sobs). They used to call me "pretty boy"; what would they say, if they saw me now? ... (Turns, and suddenly perceives the portrait.) Oh, goodness, how my heart beats! Now I know - now I am sure - that picture: (kneels down and sobs.) Yes! oh where is she now? (Hysterically.) Look at me! smile at me! remember me - mother! Mother! Mother! ${ }^{11}$

Heavily laden with melodramatic affect, the affinity between this episode and the less hyperbolic recognition scene in Brownlow's London house is very strong. In Peake's play it leads directly - give or take a few twists in various subplots - to the denouement. In Dickens's novel the "effect" (in Meisel's terms) of the scene is only of partial disclosure. Although not the most carefully plotted of novels, Dickens (with considerable help from Cruikshank), in his own recognition scene simply plants a clue as to Oliver's identity, and with a lighter touch than Brinsley Peake:

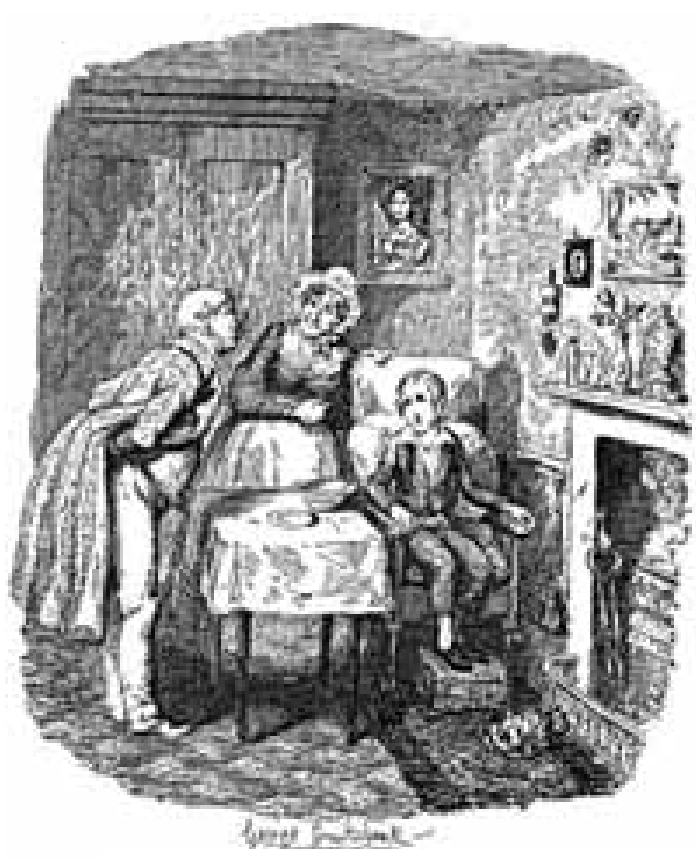

Fig 4 Oliver recovering from fever

"Is - is that a likeness, ma'am?" asked Oliver eagerly.

"Why, really, my dear, I don't know," answered the old lady in a good-humoured manner. "It's not a likeness of anybody that you or I know, I expect. It seems to strike your fancy, dear."

"It is so very pretty: so very beautiful," replied Oliver.

"Why, sure you're not afraid of it?" said the old lady, observing in great surprise the look of awe with which the child regarded the painting. "Oh no, no," returned Oliver quickly; "but the eyes look so sorrowful, and where I sit they seem fixed upon me. It makes my heart beat," added Oliver in a low voice, "as if it was alive, and wanted to speak to me, but couldn't." ${ }^{12}$

Mrs Bedwyn considerately turns Oliver to face away from the portrait, as it seems to unsettle him, and Cruikshank's accompanying tableau carefully anticipates the novel's eventual Sally Ledger, “Don't be so melodramatic!” Dickens and the affective mode. 19: Interdisciplinary Studies in the Long Nineteenth Century, 4 (2007) 
denouement, with Oliver positioned in a visual embrace, beneath his dead mother, and encircled protectively - or possessively - by Mr Brownlow and Mrs Bedwyn.

As well as emphasising the theatricality and performativity of the affective mode and its tableaux in Dickens's work, the two accounts of the first readings of The Chimes with which this essay began also draw our attention to the contiguity of tears and laughter in the listeners' response: " - shrieks of laughter ... - floods of tears." For laughter is the other main emotional affect of the melodramatic mode, a mode that Dickens explicitly defends in the seventeenth chapter of Oliver Twist. It is a well-known pronouncement, but none the less worthy of rehearsal:

It is the custom on the stage in all good, murderous melodramas, to present the tragic and the comic scenes in as regular alternation as the layers of red and white in a side of streaky, well-cured bacon. The hero sinks upon his straw bed, weighed down by fetters and misfortunes; and, in the next scene, his faithful but unconscious squire regales the audience with a comic song. We behold with throbbing bosoms the heroine in the grasp of a proud and ruthless baron, her virtue and her life alike in danger, drawing forth her dagger to preserve the one at the cost of the other; and, just as our expectations are wrought up to the highest pitch, a whistle is heard, and we are straightway transported to the great hall of the castle, where a grey-headed seneschal sings a funny chorus with a funnier body of vassals, who are free of all sorts of places from church vaults to palaces, and roam about in company, carolling perpetually.

Such changes appear absurd; but they are by no means unnatural. The transitions in real life from well-spread boards to death-beds and from mourning weeds to holiday garments, are not a whit less startling, only there we are busy actors instead of passive lookers-on; the actors in the mimic life of the theatre are blind to violent transitions and abrupt impulses of passion or feeling, which, presented before the eyes of mere spectators, are at once condemned as outrageous and preposterous. ${ }^{13}$

Dickens's novels are full of such transitions. Peter Ackroyd has written of how a group of twenty or so people attending a communal reading of The Pickwick Papers in Liverpool both laughed and cried as they made their way through the novel. One of Dickens's earliest biographers, Ackroyd tells us, visited a locksmith in Liverpool at the time of the novel's publication:

I found him reading Pickwick ... to an audience of twenty persons, literally, men, women and children. It was hired by them all for two pence a day from the circulating library, because they could not afford a shilling for the monthly number, and the observer never forgot how these humble people, who themselves could not read, laughed with Sam Weller and cried with "ready tears" at the death of the poor debtor in the Fleet Prison. ${ }^{14}$

Dickens himself, as he came to the end of the first instalment of Dombey and Son, promised Forster that the novel would include "some rollicking facetiousness, to say Sally Ledger, “Don’t be so melodramatic!” Dickens and the affective mode.

19: Interdisciplinary Studies in the Long Nineteenth Century, 4 (2007) 
nothing of pathos." ${ }^{15}$ One can think of myriad examples of Dickens's propensity to shift through the affective gears from pathos to laughter and back again. One that springs to mind is the death of Captain Hawdon, or Nemo, in Bleak House. The bleakness of his lonely death is followed by the grim satire of the 'inkwich' at which Jo's testimony is rejected on the grounds that he doesn't know his catechism, even though he is the only witness in possession of substantive evidence. The narrative then swiftly modulates into the comic melodrama of the re-enactment of the inquest at the Sols Arms public house that very same evening, with "Little Swills, the comic vocalist", parodying the Coroner's empty gravitas with some hilarity. ${ }^{16}$

What is the purpose of such modulations? I take very seriously Dickens's realismclaim in relation to the melodramatic mode and its rapid reversals. I also think, though, that the effect of such sharp affective juxtapositions is to throw into relief the moments of pathos and enable, by the force of the contrast, the reader to "re-see", or perceive anew, such affects. What I am gesturing towards here - in part at least - is a species of Brechtian "alienation effect" avant la lettre. The death of Tiny Tim in A Christmas Carol, and his subsequent resurrection, is a good example of this. In the final stave of the Carol, the "Ghost of the Future" takes Scrooge to the Cratchit household, where the man of business is struck by the family's unnatural silence. Instead of, as in his longer works of fiction (as with Little Nell, Paul Dombey, and Jo the Crossing Sweeper), lingering over a child's death, in the Carol Dickens more economically indicates Tiny Tim's death through his absence and through the palpable grief of the young boy's family: "Quiet. Very quiet. The noisy little Cratchits were as still as statues in one corner, and sat looking up at Peter, who had a book before him. The mother and her daughters were engaged in sewing. But surely they were very quiet!" The unusual silence is abruptly punctuated by Bob Cratchit's grief when he returns home from visiting his child's grave:

"... You went today then, Robert?" said his wife.

"Yes, my dear," returned Bob. "... I promised him that I would walk there on a Sunday. My little, little child!" cried Bob. "My little child!"17

The subsequent modulation from this scene of pathos and tears to one of joy, singing, and Bacchanalian festivities, as Scrooge has a change of heart and embraces Christian benevolence, owes some of its power to the force of contrast. The juxtaposition of pathos and joyous laughter means that both are more sharply framed; this is a very recognizable grammar of affect in Dickens's works of fiction.

Sally Ledger, “Don’t be so melodramatic!” Dickens and the affective mode.

19: Interdisciplinary Studies in the Long Nineteenth Century, 4 (2007) 
Another reason the revelation of Tiny Tim's death does not have the child himself at the centre of the tableau is that he is not, after all, dead. In imagining the death of Tiny Tim, and his family's brave but unavailing attempts to bear its grief, Dickens dramatizes to great emotional effect political economy's perceived assault on the working-class family. In using the supernatural ghostly mechanism of the story's dream structure, though, he is able to resurrect Tiny Tim so that by the end of the tale what the reader has experienced is simultaneously an attack on, and a defence and reaffirmation of, working-class domesticity. The protection of the integrity of the working-class family had been a central concern of anti-poor law literature from the mid-1830s and into the 1840s and beyond, and it is a concern that is expressed with great poignancy in A Christmas Carol. ${ }^{18}$ It is Dickens's dual vision that ensured the popularity of this his first Christmas Book: his attack on political economy and the individualism that went with it is hard-hitting; but it is seasonally ameliorated by his Bacchanalian vision of plenty at Christmas time.

The death of Jo the crossing sweeper in Bleak House, whilst equally laden with emotional affects, is unameliorated by any such shift from pathos to laughter and festivity. It does, though, shift between pathos and satire, and with a comparable effect. Here the tableau gathers together a whole multitude of the novel's motifs in what Martin Meisel describes as a form of montage. ${ }^{19}$ The performativity of Dickens's meticulous staging of Jo's death, and his persistent coupling of melodrama with satire, are both pronounced in this scene. As with the juxtaposition of tears and laughter, grief and joy, here the rapid shifts between melodramatic pathos and socio-political satire sharpen the rhetorical effects of both. In a novel that hinges - like all good melodramas - on a disputed will, the title of the chapter in which Jo dies ("Jo's Will") is itself simultaneously satirical and full of pathos. Mr Snagsby, the kindly legal stationer whose best effort is to offer Jo a series of half crowns, is summonsed to the ailing boy's bedside, as he has a dying wish that he wants to relate:

"What I wos a thinkin on, Mr Sangsby," proceeds Jo, "wos as you wos able to write wery large, p'raps?"

"Yes, Jo, please God," returns the stationer.

"Uncommon precious large, p'raps?" says Jo, with eagerness.

"Yes, my poor boy."

Jo laughs with pleasure. "Wot I was a thinkin on then, Mr Sangsby, wos, that when I was moved on as fur as ever I could go and couldn't be moved no furder, whether you might be so good p'raps, as to write out, wery large so that anyone could see it anywheres, as that I wos wery truly hearty sorry that I done it and that I never

Sally Ledger, “Don't be so melodramatic!” Dickens and the affective mode.

19: Interdisciplinary Studies in the Long Nineteenth Century, 4 (2007) 
went fur to do it; and that though I didn't know nothink at all, I knowd as Mr Woodcot once cried over it and was allus grieved over it, and that I hoped as he'd be able to forgiv me in his mind. If the writin could be made to say it wery large, he might."

"It shall say it, Jo. Very large." 20

Jo's moral awareness and sympathy are poignantly combined with a child-like apprehension that the writing of his apology in a large hand will increase its effectiveness. The boy's repeated assertion throughout the novel that "I don't know nothink!" here comes to a poignant climax when Jo shows himself to have a quite remarkable knowledge after all; not of letters or of scripture, but of people's feelings and of their sufferings, an intuitive moral sensibility that Dickens valued above all other forms of knowledge.

Allan Woodcourt's attempt to teach Jo the Lord's Prayer as he draws his last, laboured breaths is at once poignant and sharply discomfiting:

"Jo! Did you ever know a prayer?"

"Never know'd nothink, sir."

"Not so much as one short prayer?"

"No, sir. Nothink at all. Mr Chadbands he wos a prayin wunst at Mr Sangsby's and I heerd him, but he sounded as if he wos a speakin' to his-self, and not to me. ... I never knowd what it wos all about."

...

"Jo, my poor fellow!"

"I hear you, sir, in the dark, but I'm a gropin - a gropin - let me catch hold of your hand."

"Jo, can you say what I say?"

"I'll say anythink as you say, sir, for I knows it's good."

"OUR FATHER."

"Our Father! - yes, that's wery good, sir."

"WHICH ART IN HEAVEN."

"Art in Heaven - is the light a comin, sir?"

"It is close at hand. HALLOWED BE THY NAME!"

"Hallowed be - thy - "

The light is come upon the dark benighted way. Dead!

Dead, your Majesty. Dead, my lords and gentleman. Dead, Right Reverends and Wrong Reverends of every order. Dead, men and women, born with Heavenly compassion in your hearts. And dying this around us, every day. ${ }^{21}$

The satirical accretions around religion and prayer in the course of the novel here come to a climax: as well as knowing that Esther's illness caused much sorrow, Jo also knows that Chadband's prayers are self-serving. The poignancy of Woodcourt's simple, well-meant attempt to teach Jo the Lord's Prayer as he dies none the less leaves the reader feeling profoundly uncomfortable given the adjacent satire on Chadband's prayer-making.

Sally Ledger, “Don’t be so melodramatic!” Dickens and the affective mode.

19: Interdisciplinary Studies in the Long Nineteenth Century, 4 (2007) 
Martin Meisel's account of the chapter detailing Jo's death as a form of montage emphasises the auditory effects of the piling up of motifs: "'moving on', ... prayer and knowing 'nothink' ... the dark, and the light that is coming ... [all] rise to a rhythmic climax [to produce] a violent annunciation of death. The organisation of improvised, verbal-thematic elements to achieve this effect is rhetorical and perhaps more musical than pictorial." $^{22}$

The intervention of the narrator at the close of the chapter - the diegesis as opposed to the mimesis of the text - sharply removes the reader from the tableau, reminding us that it is a tableau, an effect, a rhetorical set-piece. Drawing attention to the performed, staged nature of Jo's death has, again, a reality effect. And whilst in $A$ Christmas Carol Dickens's weeping readers could blame the Scrooges of the world for the plight of the Cratchit family, ten years later they are forced to look at themselves - it is "us" around whom such children die every day.

Jo's deathbed scene, along with Esther's emotionally fraught reunion with her longlost mother, is a melodramatic set-piece in a novel in which Dickens frequently challenges the melodramatic mode even as he embraces it. Never simply embracing the melodrama except, perhaps, in Oliver Twist - Dickens's negotiation of and dialogue with this popular cultural mode became politically more complex as he headed into the 1850s. John Stuart Mill strongly disparaged Bleak House because, as he thought, "It is done in the very vulgarest way - just the style in which vulgar men used to ridicule 'learned ladies' as neglecting their children and household." ${ }^{23}$ It is Dickens’s satirical account of Mrs Jellyby to which Mill objects, the champion of "Telescopic Philanthropy" later dropping this project in favour of agitating for women's political rights. Dickens's satire is harsh, and yet it could be argued that Mrs Jellyby's endless writing of letters, her setting up of committees and societies and other such institutional paraphernalia simply mimic the (patriarchal) mechanisms of Chancery, which are shown in the novel to be so pointless and destructive: like Krook, she is said to live amidst "waste and ruin". ${ }^{24}$ Mill, though, is right that Mrs Jellyby is an unsympathetic lampoon of women philanthropists and activists of the mid-century. But the satire is played off against a range of melodramatic female types in the novel which tell an entirely different story, one that promotes a powerful critique of women's oppression at the mid-century. The domestic angel that forms part the least knowing part - of Esther Summerson's self-identity is a near relation to the

Sally Ledger, “Don’t be so melodramatic!” Dickens and the affective mode.

19: Interdisciplinary Studies in the Long Nineteenth Century, 4 (2007) 
heroine of domestic melodrama, and many of the other female figures in the novel have melodramatic antecedents: the imperious Lady Dedlock echoes the archetypal fallen woman; the French maid, Hortense, is the deadly foreign murderess (apparently modelled on Maria Manning); Jenny the bricklayer's wife the victim of domestic brutality; young Charley the orphan mother. These types, though, are not fixed in the novel. Lady Dedlock, the Lady of the Manor, merges, towards the novel's close, with the archetypal figure of the prostitute who drowns herself in the Thames: the "doubling" of aristocratic lady and forsaken prostitute is carefully staged. As Esther and Inspector Bucket search London for Lady Dedlock, Esther spots a poster, on a "mouldering wall" by the Thames, on which she can discern the words "FOUND DROWNED", which fills her, she tells us, with "an awful suspicion shadowed forth in our visit to that place":

A man yet dark and muddy in long, swollen sodden boots and a hat like them, was called out of a boat, and whispered with Mr Bucket, who went away with him down some slippery steps -as if to look at something secret that he had to show. They came back, wiping their hands upon their coats, after turning over something wet; but thank God it was not what I feared! ${ }^{25}$

There is a whole series of mistaken female identities in the novel. Mistaken identity is a staple ingredient of melodrama, but it has a profound implication for Dickens's class-

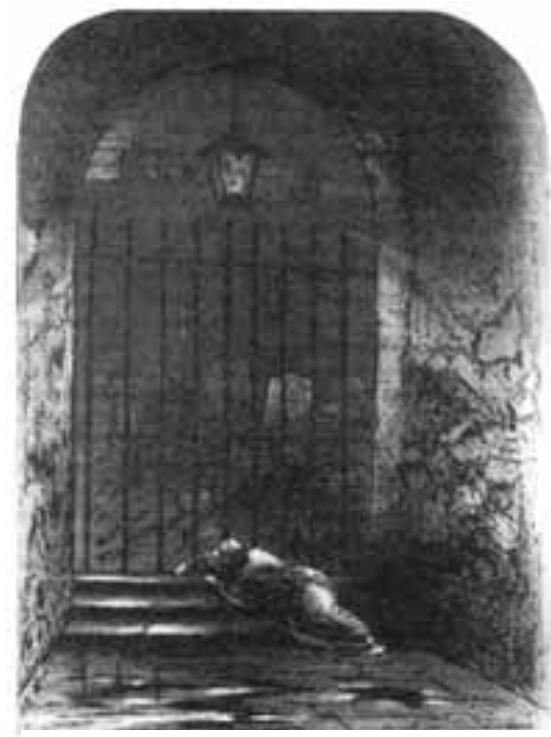

Fig 5 The Morning inflected account of femininity in Bleak House. Lady Dedlock is mistaken -designedly so - for Hortense, her maid; Jo mistakes both Hortense and Esther for Lady Dedlock; and Esther mistakes her own dead mother for Jenny, the brutal bricklayer's wife (see figure 5):

On the step at the gate, drenched in a fearful wet of such a place, which oozed and splashed down everything, I saw, with a cry of pity and horror, a woman lying Jenny, the mother of the dead child. ... She lay there, who had so lately spoken to my mother. She lay there, a distressed, unsheltered, senseless creature. ... I passed on to the gate, and stooped down. I lifted the heavy head, put the long dank hair aside, and turned the face. And it was my mother, cold and dead. ${ }^{26}$

The drowned prostitute, the brutalised bricklayer's wife, the dead Lady of the Manor: all converge in Esther's long search for her mother. Both Jenny, the bricklayers' wife, and Lady Dedlock, the wife of a Baronet, have lost their babies: the one to poverty and disease, the other to the moral codes of social propriety. Their equality in victimhood is Sally Ledger, “Don’t be so melodramatic!” Dickens and the affective mode.

19: Interdisciplinary Studies in the Long Nineteenth Century, 4 (2007) 
dramatically expressed in the above scene, Dickens engaging here and throughout the novel in a cross-class account of women's oppression. It is an account that depends entirely on his negotiation of the melodramatic mode.

I want to close by returning to one of the excerpts with which this essay began: Gilbert À Beckett's comment in relation to The Chimes that "he believed it". My proposal is that what writers of melodrama - Dickens included - were aspiring to, was a realism of affect, rather than to a representational realism. Dickens is fully aware - as his readers at the time would have been - that neither the supernatural devices used in the Carol, nor the highly rhetorical staging of Jo's death in Bleak House, owe much to realism at the level of plot. He is not asking his readers to "believe in" his account of either child's death at the level of incident; but he is asking them to respond to - and to "believe in" - the emotional affects of both scenes and, thereafter, to act upon the injustices meted out to the Cratchits and the Jo's of mid-nineteenth-century Britain. In describing À Beckett's response to The Chimes in a letter to his wife, Dickens struggles to express what the story had meant to his fellow writer. He tells his wife that the weeping man had "believed it, and felt it, to be - I won't say what." 27 This rare moment of inarticulacy in Dickens seems to me to be entirely appropriate. In Bleak House Jo's literacy is affective, rather than lexical. Dickens's, usually, is both.

\section{List of Illustrations}

Figure 1: Dickens Reading The Chimes at 58 Lincoln's Inn Fields, 3 December 1844. From the drawing by Daniel Maclise in the Victoria and Albert Museum.

Figure 2: George Cruikshank, 'Oliver asking for more', illustration for Oliver Twist.

Figure 3: George Cruikshank, 'Oliver escapes being bound apprentice to the Sweep', illustration for Oliver Twist.

Figure 4: George Cruikshank, 'Oliver recovering from the fever', illustration for Oliver Twist.

Figure 5: Hablot Browne ('Phiz'), 'The Morning', illustration for Bleak House.

\footnotetext{
${ }^{1}$ Paul Schlicke, Oxford Reader's Companion to Dickens (Oxford and New York: Oxford University Press, 1999), p. 187.
}

Sally Ledger, “Don’t be so melodramatic!” Dickens and the affective mode.

19: Interdisciplinary Studies in the Long Nineteenth Century, 4 (2007) 
${ }^{2}$ Letter to Forster, 3 and [4] November 1844, Pilgrim Letters, vol. 4, p. 210. I refer throughout to the Clarendon Press twelve-volume Pilgrim edition of The Letters of Charles Dickens, abbreviated to 'Pilgrim Letters'.

${ }^{3}$ K. J. Fielding, 'Two Sketches by Maclise', Dickens Studies Annual 2 (1966), 13.

${ }^{4}$ Letter to Mrs Charles Dickens, 2 December 1844, Pilgrim Letters , vol. 4, p. 235.

${ }^{5}$ Letter to Mrs Charles Dickens, 2 December 1844, Pilgrim Letters, vol. 4, p. 234.

${ }^{6}$ Martin Meisel, Realizations: Narrative, Pictorial and Theatrical Arts in Nineteenth-Century England (Princeton: Princeton University Press, 1983), p. 83. For the centrality of melodrama to Victorian culture see also Peter Brooks, The Melodramatic Imagination: Balzac, Henry James and the Mode of Excess (New Haven: Yale University Press, 1976), Elaine Hadley, Melodramatic Tactics: Theatricalized Dissent in the English Marketplace, 1800-1885 (Stanford: Stanford University Press, 1995), and Sally Ledger, Dickens and the Popular Radical Imagination (Cambridge and New York: Cambridge University Press, 2007).

${ }^{7}$ Letter To Mrs Charles Dickens,2 December 1844, Pilgrim Letters, vol. 4, p. 235.

${ }^{8}$ R. R. Madden (ed.), The Literary Life and Correspondence of the Countess of Blessington, 3 vols (London: T.C. Newby, 1855), vol. 2, p. 400.

${ }^{9}$ Charles Dickens, Oliver Twist (1837-39; repr. Harmondsworth: Penguin, 2003), ed. Philip Horne, p. 25.

${ }^{10}$ Katherine Newey, 'Climbing Boys and Factory Girls: Popular Melodramas of Working Life', Journal of Victorian Culture 5:1 (2000), 28-44. The play is also very clearly a source for The Pickwick Papers.

${ }^{11}$ Richard Brinsley Peake, The Climbing Boy, or, The Little Sweep (1832; repr. London: Dick's Standard Plays, 1885), Act 2, p. 9.

${ }^{12}$ Dickens, Oliver Twist, p. 90.

${ }^{13}$ Ibid., p.134.

${ }^{14}$ Peter Ackroyd, Dickens (1990; repr. London: Minerva, 1991), p. 56.

${ }^{15}$ Letter to John Forster [?12 July 1846], Pilgrim Letters, vol. 4, p. 583.

${ }^{16}$ Charles Dickens, Bleak House (1852-53; repr. London and New York: Penguin Books, 2003), ed. Nicola Bradbury, chapter 11.

17 'A Christmas Carol', in The Christmas Books, (1843; repr. London: J.M. Dent, 1999), ed. Sally Ledger, pp. 73-74.

${ }^{18}$ For a full account of the anti-poor law movement's defence of the working-class family see Ledger, Dickens and the Popular Radical Imagination, chapter 3.

${ }^{19}$ Meisel, Realizations, p. 61.

${ }^{20}$ Dickens, Bleak House, p. 731.

${ }^{21}$ Ibid., pp. 731-734.

${ }^{22}$ Meisel, Realizations, p. 61.

${ }^{23}$ John Stuart Mill, Letter to Harriet Taylor, 20 March 1854, in Philip Collins (ed.), Dickens: The Critical Heritage (London: Routledge and Kegan Paul, 1971), p. 298.

${ }^{24}$ Dickens, Bleak House, p. 480.

${ }^{25}$ Ibid., p. 827.

Sally Ledger, “Don’t be so melodramatic!” Dickens and the affective mode. 19: Interdisciplinary Studies in the Long Nineteenth Century, 4 (2007) www.19.bbk.ac.uk 
${ }^{26}$ Ibid., pp. 868-869.

${ }^{27}$ See note 5 .

Sally Ledger, “Don't be so melodramatic!” Dickens and the affective mode.

19: Interdisciplinary Studies in the Long Nineteenth Century, 4 (2007) 